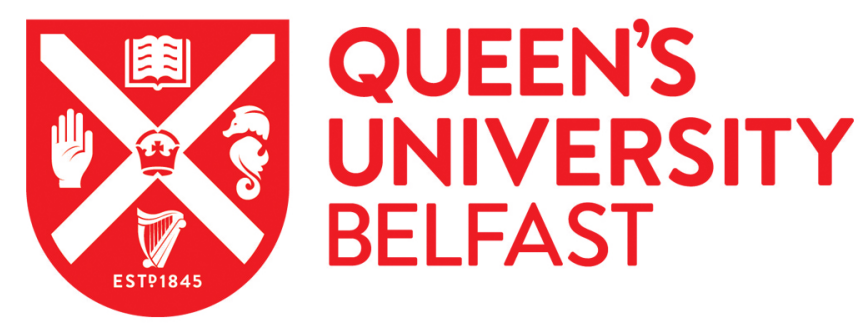

\title{
Isometric growth in the world's largest bony fishes (genus Mola)? Morphological insights from fisheries bycatch data
}

Phillips, N. D., Kubicek, L., Payne, N. L., Harrod, C., Eagling, L. E., Carson, C. D., Cappanera, V., \& Houghton, J. D. R. (2018). Isometric growth in the world's largest bony fishes (genus Mola)? Morphological insights from fisheries bycatch data. Journal of morphology. https://doi.org/10.1002/jmor.20872

Published in:

Journal of morphology

Document Version:

Peer reviewed version

Queen's University Belfast - Research Portal:

Link to publication record in Queen's University Belfast Research Portal

Publisher rights

(c) 2018 Wiley Periodicals, Inc. This work is made available online in accordance with the publisher's policies. Please refer to any applicable terms of use of the publisher.

\section{General rights}

Copyright for the publications made accessible via the Queen's University Belfast Research Portal is retained by the author(s) and / or other copyright owners and it is a condition of accessing these publications that users recognise and abide by the legal requirements associated with these rights.

Take down policy

The Research Portal is Queen's institutional repository that provides access to Queen's research output. Every effort has been made to ensure that content in the Research Portal does not infringe any person's rights, or applicable UK laws. If you discover content in the Research Portal that you believe breaches copyright or violates any law, please contact openaccess@qub.ac.uk. 


\section{Isometric growth in the world's largest bony fishes (Genus Mola)? Morphological insights from fisheries bycatch data}

Natasha D. Phillips ${ }^{1 *}$, Lukas Kubicek ${ }^{2}$, Nicholas L. Payne ${ }^{3}$, Chris Harrod $^{4}$, Lawrence E. Eagling ${ }^{5}$, Carol D. Carson ${ }^{6}$, Valentina Cappanera ${ }^{7}$, Jonathan D.R. Houghton ${ }^{1,5,8}$

${ }^{1}$ Queen's University Belfast, School of Biological Sciences, 97 Lisburn Road, Belfast, BT9 7BL, Northern Ireland; ${ }^{2}$ Aussermattweg 22, 3532 ,

Zäziwil, Switzerland; ${ }^{3}$ Department of Life Sciences, University of Roehampton, Holybourne Avenue, London, SW15 4JD; ${ }^{4}$ Instituto de Ciencias Naturales Alexander von Humboldt, University of Antofagasta, Avenue Argentina 2000, Antofagasta, Chile; ${ }^{5}$ Queen's Marine Laboratory, $12-13$ The Strand, Portaferry, BT22 1PF; ${ }^{6}$ The New England Coastal Wildlife Alliance, 11 Clarence Soule Drive, Middleboro, MA 02346; ${ }^{7}$ Area Marina Protetta di Portofino, Ministry for the Environment and for the Protection of Territory and Sea, Santa Margherita Ligure, Genova, Italy; ${ }^{8}$ Institute of Global Food Security, Queen's University Belfast, 18-30 Malone Road, Belfast, BT9 5BN, U.K.

\section{Short title: Ocean sunfish growth and morphometrics}

*Author to whom correspondence should be addressed: Natasha Phillips, Queen's University Belfast, Medical Biology Centre, 97 Lisburn Road, Belfast, BT9 7AE; nphillips01@qub.ac.uk 


\begin{abstract}
For fishes, the relationship between morphometric traits can provide significant insight into species life history, however gathering such data for non-commercial species can prove challenging. Here we use data collected opportunistically from fisheries bycatch and stranding events to assess growth scaling over orders of magnitude in the ocean sunfish (Genus Mola). Intriguingly, the confidence intervals for the relationship between length and mass suggests that isometric scaling is likely, a growth pattern rarely observed in fishes owing to the scaling of supportive structures. These data also enabled assessment of geometric morphometrics, which indicated that Mola shape varies subtly but significantly ontogenetically, with increased fin area comparative to body area as fish increase in size. More practically, total length emerged as an effective predictor for a range of morphological traits, including mass, fin lengths and surface area, which can provide vital baseline data for fisheries modelling and management.
\end{abstract}

\title{
Key words:
}

Allometry, Isometric Scaling, Geometric Morphometrics, Ocean Sunfish, Mola

\section{Research highlights:}


Bycatch data provides new insight into ocean sunfish morphometrics and baseline data for fisheries management, where total length provides an effective predictor of morphological traits, with the potential for isometric scaling of mass with length.

\section{Introduction}

As organisms develop, the relationship between size and shape can have significant effects on species ecology (Fu et al., 2016); including changes in habitat or diet (e.g. Werner \& Gillian, 1984; Eggold \& Motta, 1992; Carrier, 2010). Beyond functional ecology, such scaling concepts are increasingly being transferred from describing simple anatomical relationships in the biosciences to a wide range of disciplines as an axiom for growth, or expansion in general. For example, the scaling of road networks has been likened to blood vessels, whilst commercial rubbish collection is analogous to the disposal of biological waste products (Samaniego \& Moses, 2008; West, 2017). In light of such increased interest in the allometry of growth, it appears timely to consider a group which undergoes perhaps the greatest growth scaling of any animal; that of the ocean sunfishes (Genus Mola, Linnaeus 1857), with data collected for this study suggesting an increase in mass approximately $10^{8}$ fold over the lifetime of an individual. The sheer size range of this genus provides a rare opportunity to explore growth scaling over many orders of magnitude, illuminating how biological functioning adapts and hydrodynamics may shift as size increases (Spence, 2009).

In fish, the relationship between length and mass is of particular value (Cadrin \& Friedland, 1999), and can help to estimate species trophic level when ontogenetic shifts in diet are known (Jennings, Barnes, Sweeting, \& Polunin, 2008). Significant ontogenetic shifts have been reported in 
ocean sunfishes (e.g. Syväranta et al., 2012; Harrod et al., 2013; Nakamura and Sato, 2014; Sousa et al., 2016a), however additional morphometric and size-frequency data are needed in order to include this species in ecosystem or fisheries models. Indeed, as it is now established that sunfishes in seasonal hotspots can occur in high abundance (Phillips et al., 2017; Sims et al., 2009; Sousa et al., 2016; Thys et al., 2017), with individuals $<1 \mathrm{~m}$ TL feeding broadly at the seabed and in the water column (Nakamura \& Sato, 2014; Syväranta et al., 2012), their current omission from such models is somewhat problematic. By extension, the mass removal of sunfishes globally as by-catch each year (e.g. Silvani et al., 1999; Cartamil and Lowe, 2004; Petersen and McDonell, 2007) has the potential to drive localised trophic cascades when such significant top-down control is reduced.

For non-commercial species the acquisition of such morphological or demographic data can be financially and logistically demanding, although opportunities arise when individuals are regularly caught and reported as bycatch (e.g. Lee \& Brown, 1998; Beddington et al., 2007; Carlson, 2017). However, with the mass bycatch of Mola often resulting in hundreds or even thousands of individuals accidentally captured at once (see review; Pope et al., 2010), it would be unfeasible for a fisheries observer to measure every morphological trait and collect mass data during a typical fishing operation. Thus emerges the need for a simple metric that can be collected rapidly at sea, and converted retrospectively into a range of morphological traits. To this aim we provide conversion equations derived from $>568$ sunfish ranging in length from $0.025<3.3 \mathrm{~m}$. Specifically, we tested the efficacy of total length (a routine measurement in fisheries research) as a predictor of key morphological traits including body mass, fin lengths and surface area. These data enabled detailed assessment of growth scaling across orders of magnitude, alongside ontogenetic variation in the sunfish bauplan with implications discussed for species ecology. 


\section{Materials and Methods}

\section{Data Collection and Treatment}

In this study we aimed to characterise the allometry of the genus Mola, currently believed to contain three species; M. mola, M. alexandrini and M. tecta. Alongside these cryptic species, evidence suggests that the genus Mola may contain further distinct species or subspecies but additional genetics research will be required to investigate how distinct these groupings are (Bass et al., 2005; Nyegaard et al., 2017; Pope et al., 2009;

Sawai et al., 2017a; Sawai et al., 2017b; Yoshita et al., 2009). Since all species in the genus Mola have very similar gross morphology, misidentification of newly described species (particularly concerning historic specimens) can occur and genetic techniques are often required to confirm species identification. As our data were gathered from the literature or field observations prior to new species descriptions being published, we have conducted our analysis at genus level to avoid misidentification errors. Since our results do not cluster into distinct groups and are largely devoid of outliers, we are confident that the genus can be grouped together for gross morphological analysis without skewing our findings.

Measurements and photographs of Mola bycatch were collected (Figures 1 \& 2) and additional data collated from published papers (e.g. Dewar et al., 2010; Nakamura et al., 2015; Thys et al., 2015), sightings databases (e.g. McClain et al., 2015a), internet sources and personal communications (for full list of measurements and original data sources please see Appendix S1. in Supplementary Materials). To extract further 
straight-line measurements of fish from photographs and avoid distortion from affecting analysis, strict criteria were applied to the collection of photographic data. All photographs were taken directly above fishes laid on a flat surface at approximately $1 \mathrm{~m}$ in height, with a standard tape measure in frame. Once the photographs were collected, ImageJ software was used (Schneider, Rasband, \& Eliceiri, 2012) to derive the following information; body: total length, width, area and shape; fins (dorsal, anal and pectoral): length and width; fins (dorsal and anal only): area and shape; eye diameter, mouth size, clavus width and mass $(n=568$ individuals, total length range: $0.025<3.3 \mathrm{~m})$.

Growth Scaling

To test our hypothesis that Mola growth should be classed as allometric, the relationship between multiple morphometric traits needed to be defined. Each variable was plotted against total length (see Fig. 3) using programing software R (R Development Core Team, 2008), using package 'FSA' (Ogle, 2017), following the methods of Ogle (2013). In order to apply linear models to this dataset, all morphometric data were $\log _{\mathrm{e}}$ transformed (Ogle, 2013), stabilising the variance around the model and making errors additive, rather than multiplicative. However, variability on the $\log _{\mathrm{e}}$ scale appeared far greater for larvae samples, which suggested that these measurements lacked precision in comparison to the larger fish (Ogle, 2013). Since we were not able to verify the accuracy of these archived data, fish with a loge mass of less than $0.9(\mathrm{n}=6)$ were removed from the analysis to ensure scale precision and the linear models rerun.

If fish scale isometrically, then body shape remains constant as the animal grows, with volume proportional to length (or any linear measurement). If mass if taken as a proxy for volume, and total length provides a linear measurement, then the estimated slope of the model 
relationship (b) between length and mass must equal three for isometric growth. However, isometric growth is not commonly observed in fish (Bolger \& Connolly, 1989; Ogle, 2013), so following these methods, the slope of each linear model was estimated with 95\% confidence intervals to classify growth scaling.

\section{Fish Bauplan}

Given that Mola fin aspect ratio varies with growth (Watanabe \& Sato, 2008), we extended these analyses to consider whether dorsal and anal fins provide the same proportional area ontogenetically. To assess the scaling of fins, several analyses were run. Firstly, total fin surface area (sum of dorsal and anal fin area) was calculated as a proportion of body surface area, and then regressed against total length. Secondly, we tested for a relationship between fin aspect ratio and total length, again using linear regression.

To assess if the ocean sunfish bauplan changes ontogenetically, geometric morphometrics were assessed using landmark analysis (see Figure 4). For these analyses, only photographs where the entire fish was in view and with a known total length could be used $(n=71)$. Landmarks were set around the perimeter of each specimen at specific points (Klingenberg, 2011) and the fish categorised into three size classes: small $\left(<25^{\text {th }}\right.$ percentile), medium $\left(25^{\text {th }}<75^{\text {th }}\right.$ percentile $)$ and large $\left(>75^{\text {th }}\right.$ percentile). To control for variation in size, we ran a regression to assess the relationship between centroid size and Procrustes distance of sunfish shapes. This suggested there was no significant affect (TSS 0.997, $\mathrm{p}$ value $>0.05$ ) and so any observed difference in landmarks between specimens then would be due to significant variation in shape of the fish (Polly, 
2013). A covariance matrix was used to compare the shapes of fish from differing size classes and the landmark data assessed using Principle Component Analysis (PCA), illustrated by warped wireframe models, and tested using an ANOVA (Klingenberg, 2011).

\section{Results}

Linear Models

In this study, data were collected from 568 sunfishes ranging in body length from $0.3 \mathrm{~cm}<330 \mathrm{~cm}$ and in body mass from $0.01 \mathrm{~g}<3,500,000 \mathrm{~g}$ (3.5 tonnes). The morphometric measurements taken were all noted to be strongly correlated with individual length, however some variation can be seen, such as between the mass and length of the largest individuals recorded (Figure 3). All measured Mola traits can be tentatively classed as scaling allometrically (for full results of linear models see Table 1, with plots shown in Figure 3 and Supplementary Materials), with the estimated slope of the linear model always resulting in a value less than three, aside from the relationship between body mass and total length which suggested isometric scaling was highly likely. The slope of the line between these variables was estimated as 3.09 (+/- 0.08 at $95 \%$ CI) with a strong correlation coefficient (0.98). To consider if the fin propulsive area changes ontogenetically, the surface area of Mola dorsal and anal fins was considered as a proportion of body surface area and modelled against total length of fish. The results $\left(\mathrm{R}^{2}=0.26, \mathrm{~F}\right.$ statistic $=19.96$ with $56 \mathrm{DF}, \mathrm{P}<0.05)$ suggested that Mola fins are subject to a slight but significant increase in proportion to body area ontogenetically, however increased numbers of larger fish measurements will be required to confirm this relationship, particularly in light of the wide variation 
between smaller individuals. The aspect ratio for both dorsal and anal fins was calculated at approximately 2:1. The regression analysis suggested a slight negative relationship between aspect ratio and fish total length for the anal fin $\left(\mathrm{R}^{2}=0.013, \mathrm{~F}\right.$ statistic $=13.7$ with $94 \mathrm{DF}, \mathrm{P}<$ $0.05)$ but this was not significant for the dorsal fin $\left(\mathrm{R}^{2}=0.009\right.$, F statistic $=0.93$ with $\left.98 \mathrm{DF}, \mathrm{P}>0.05\right)$.

\section{Geometric Morphometrics}

The results of the landmark analysis suggested that even when controlling for size, there was some considerable variation in Mola body shape (Figs. 4, 5 \& 6.) The PCA results of the landmark analysis (Table 2) suggested that PC1 explained 25.3\% of the variance in sunfish shape and PC2 a further $21.0 \%$ of the variance. $71.7 \%$ of the variation was explained by four components and the total variance by 16 components. The results suggested that landmark 1 (tip of snout), landmark 2 (tip of clavus) and landmark 4 (tip of dorsal fin) were the most variable in shape.

The PCA morphospace plot (Fig. 5) illustrates the first and second principle components of Mola shape which suggests there may be some significant variation in body shape ontogenetically. From these data, it appeared that the smaller size classes clustered positively in PC1 becoming slightly negative as total length increased, however it appears that heterogeneity increases with total length.

To isolate specific shape changes, warped grid models were created to illustrate Mola shape alterations along the PC1 axis (Fig. 6). These figures suggested that for fish in the smaller size class, the shape becomes tighter with landmarks positioned closer together and the fintips appeared slightly more elongated and angled towards the snout of the fish. As the PC1 scale decreased towards the larger size fish, the body shape had landmarks more widely spaced, with the snout tip protruding further and fin tips appearing slightly shorter and angled further back towards the 
clavus. To test whether Mola shape was related to size, an ANOVA was run on the PCA shape data, which suggested a significant change in Mola shape across size classes $\left(\mathrm{F}_{1088,32}=5.24, \mathrm{P}<0.05\right)$.

\section{Discussion}

Length/Mass Relationships and Prediction of Morphological Traits

Modelling the relationships between fish morphometric traits has been scrutinised in recent years as a routine analysis that provides limited information (Hilborn \& Walters, 2001). However, such relationships are only known for a relatively small number of species (Kulbicki, Guillemot, \& Amanda, 2005) and can provide significant insight into ontogenetic differences in species ecology (Werner \& Gillian, 1984; Eggold \& Motta, 1992; Weston, 2003; Carrier, 2010; Fu et al., 2016). The shift from more traditional morphometric analyses to incorporate new geometric morphometrics has provided biologists with more powerful tools for shape analysis (Bookstein, 1996, 1997; Zelditch et al., 2004), which enables characterisation of growth and visualisation of allometry (Alberch et al., 1979; Klingenberg, 1996; Loy et al., 1995). One of the earliest attempts to quantitatively describe the mechanism of shape changes in the natural world focused on the transformation of the puffer fish (Diodon) bauplan (which shares a common ancestor with the sunfishes) to that of Mola (Thompson, 1917). Here we return to examine the morphology of ocean sunfishes in further detail using a combination of methods to measure Mola growth across multiple morphometric traits and assess ontogenetic shape changes. 
From the results of this study, we suggest that total length provides an effective predictor of key morphological traits in Mola. It is worth noting that a degree of individual variation is apparent in the data, such as in the mass/length relationship among larger specimens, but this may occur as a function of body condition or reproductive efforts. Since the ability to accurately predict multiple measurements can provide baseline data for fisheries modelling, including size-based models (see review: Giacomini et al., 2016), mass-length analysis (e.g. Murphy et al., 1991; Blackwell et al., 2000; Froese, 2006), mass balance models (e.g. Vasconcellos et al., 1997; Jarre-Teichmann, 1998) and estimation of fish trophic level (e.g. Dickie et al., 1987; Jennings et al., 2008), the results of the linear models described here may be of considerable use to fisheries scientists, enabling estimation of 16 traits from a single measurement. Without routine collection of sunfish data, we cannot progress to consider the size frequency of populations; however these data present a baseline for such efforts.

Since the morphological measurements presented here were collected from multiple locations across the globe, we suggest there is a commonality in growth patterns between species within the genus Mola and between populations, which is intriguing given that ocean sunfishes are pan-globally distributed, ranging from oligotrophic to highly productive systems. As wide-ranging marine vertebrates are likely to encounter human activities, such as industrial fisheries, which may place them at risk, it is necessary to gain a thorough understanding of species ecology as management of anthropogenic activities at sea is a complex process, often involving multiple nations and regions where limited legal conventions are available (Witt et al., 2014). By providing the relationships between total length and a variety of traits in this study, we aim to boost data recording capabilities by enabling extensive morphometric databases to be rapidly collected for an understudied taxa in urgent need of informed management (see Fig. 1). 


\section{Growth Scaling}

In this study, almost all measured traits of Mola can be classified as scaling allometrically with total length. However, the relationship between mass and length appears likely to scale isometrically with a b estimate of 3.09 (+/- $0.08 \mathrm{CI})$. Recent debate on use of statistics in scientific research suggests an over-reliance on $\mathrm{p}$ values to provide definitive significance between variables has led to a decline in reliability and reproducibility of results (e.g. Halsey et al., 2015). As alternative methods of statistical interpretation are proposed, here we use one of the more intuitive and tractable methods suggested by reporting the $95 \%$ confidence interval aided by graphical presentation (Halsey et al., 2015). The estimated slope of the mass/total length linear model classes the relationship as on the borderline between isometric and allometric growth $(b=$ 3.09). However, following similar reporting mechanisms in the recent literature (Gagnat et al., 2016; Rosli \& Isa, 2012), if we consider that the true slope of the line is somewhere between 3.01 and 3.12, with a strong correlation coefficient (0.98), we suggest that a b exponent of $\sim 3$ is highly likely, although there is some variation between individuals.

More broadly, the potential for isometric scaling is of particular interest as such growth patterns are relatively rare in fish species under natural conditions (Bolger \& Connolly, 1989; Mazumder et al., 2016; Ogle, 2013); given that fish body shape and density typically changes with growth and body condition (Lagler, 1966; Le Cren, 1951; Mazumder et al., 2016; Wootton, 1990). Although fish growth is frequently estimated as scaling isometrically to facilitate calculations when retrospectively deriving mass from length (Froese, 2006), greater precision is required when classifying the growth scaling of species ontogenetically. More specifically, the exact value of the scaling exponent is rarely 3.00 (Ogle, 2017) with significant variance between taxa (McClain et al., 2015b). True isometric scaling of mass and length primarily occurs in taxa with 
hydrostatic skeletons which provide skeletal support but lack rigid elements (Quillin, 1998), as isometrically scaled support structures typically become untenable in larger organisms due to skeletal mechanical limits (Spence, 2009). Animals with rigid skeletons are likely to scale allometrically to support increased mass loading with growth, and thereby avoiding compression failure or buckling as mass increases (Kurth \& Kier, 2014). The ocean sunfishes' skeleton may enable isometric scaling, as unlike typical calcified bone, ocean sunfish skeletal tissue is relatively soft and flexible (pers. coms. Watanabe, 2015; pers. obs.), and so it is possible that this provides a combination of support and compressibility to avoid collapsing as fish increase in mass.

The shape of Mola is also relevant when categorising scaling, as the results from our study suggest that sunfish do not grow significantly "plumper" as length increases (Blackwell et al., 2000; Froese, 2006), which corresponds with our current understanding of Mola physiology, and how it changes ontogenetically (Fraser-Brunner, 1951). From our observations of Mola at differing stages of ontogeny, the shape of individuals appears relatively uniform in comparison to a typical thunniform fish (which become considerably broader ontogenetically) and so it may be possible for some individuals to retain body shape and specific gravity as they grow (Lagler, 1966; Wootton, 1990).

A study of the largest oceanic taxa by McClain et al. (2015b) suggested an allometric relationship occurred between total length and body mass of M. mola $(\mathrm{b}=3.19, \mathrm{n}=132)$. However, when we incorporated these data sources into the analysis presented here $(\mathrm{n}=568)$, the combined results suggested that overall, an isometric relationship was possible. Both studies were subject to similar limitations, with Mola size and mass data skewed towards smaller individuals, but by incorporating additional data, we aimed to build on this initial analysis; (McClain et al., 2015b size and mass ranges respectively: $0.38 \mathrm{~m}<2.9 \mathrm{~m} ; 2.65 \mathrm{~kg}<2300 \mathrm{~kg}$, of which 6 individuals $>500 \mathrm{~kg}$; this study data: size and mass ranges 
respectively $0.025 \mathrm{~m}<3.3 \mathrm{~m} ; 0.00001 \mathrm{~kg}<3500 \mathrm{~kg}$; of which 15 individuals $>500 \mathrm{~kg}$ ). In order to explore the potential for and ecological implications of isometric growth, further research into the three dimensional shape of sunfishes is required and an increased understanding of skeletal composition may provide new insight into sunfish loading capabilities.

Morphometric Analysis

Watanabe \& Sato (2008) suggested that sunfish fin shape varies ontogenetically $(\mathrm{n}=49)$ from narrow, tall fins in smaller fish $(\sim 2 \mathrm{~kg})$, to comparatively shorter, wider fins in larger fish $(\sim 950 \mathrm{~kg})$. However within this study, although the total fin area increased significantly with body size $(n=56$, mass $=2<2500 \mathrm{~kg})$, the aspect ratio differed between the fins, with a slight negative relationship noted in the anal fin $(\mathrm{n}=$ 99), but not for the dorsal fin $(\mathrm{n}=102)$. Although our findings differ to some extent with those of Watanabe \& Sato (2008), we acknowledge the inherent skew in our data towards smaller individuals. Further investigation is therefore recommended with increased samples of larger specimens, to establish precisely how fin shape varies with size and the ecological implications of this change in shape. Minor discrepancies aside, if the fin aspect ratio declines with growth, swimming efficiency is likely to decrease as animals grow (Liebe, 2007) as a lower aspect ratio produces less lift and increased drag, resulting in reduced locomotive efficiency (Vogel, 1994). However, it appears that total fin area significantly increases comparative to body size as fish grow, providing a greater propulsive area which may partially compensate for the effects of a declining aspect ratio. 
Beyond shifts in size and shape, the positioning of the dorsal and anal fins may also vary as individuals grow. Specifically, it appears that the adult sunfish bauplan alters subtlety but significantly with size, although further research is required to ultimately determine if these changes affect fish locomotion. Of particular note is the changing position of the fin tips in relation to body size; with fin tips positioned towards the snout in smaller fish, and angled slightly towards the clavus in larger specimens. This appears to mimic aircraft wing positioning, where swept forward wings increase manoeuvrability, straight wings provide most lift and swept back wings reduce drag (Loftin, 1985). If we can apply these concepts to fish fin tip position, it might suggest that smaller fish may benefit from increased lift and manoeuvrability, whereas reducing drag is of greater benefit to larger fish. When considering hydrodynamic effects allometrically, it is difficult to suggest which fish shapes are likely to produce the lowest overall drag (Vogel, 1994), and this will require further investigation to consider the scaling costs of transport for sunfishes and how this may be linked to ontogenetic shifts in habitat and diet.

\section{Conclusions}

Taken together, the results of this study suggests that Mola growth scaling can be tentatively classed as allometric, although we propose that mass may scale isometrically with length. Alongside these relationships, the data suggest that total length provides an effective tool to predict a range of morphological traits where the Mola bauplan appears to vary subtly with growth, which may have implications for energetic requirements and dietary shifts of Mola ontogenetically. 


\section{Authors' contributions}

NDP, JH \& $\mathrm{CH}$ conceived the ideas

NDP \& NP designed the methodology

NDP, LE, VC, LK \& CC collected the data

NDP analysed the data

NDP \& JH led the writing of the manuscript

All authors contributed critically to the drafts and gave final approval for publication.

\section{Acknowledgements}

The authors would like to acknowledge the vital supportive role of the Portofino Marine Protected Area Authorities and the numerous days at sea enabled by the fishermen of the Camogli Tonnarella for data collection. We are also very grateful to all the persons who donated sunfish photographs and measurements to this study and to the Fisheries Society of the British Isles for funding the studentship of Natasha Phillips. 


\section{Compliance with Ethical Standards}

Funding: This study was funded by a studentship grant from the Fisheries Society of the British Isles.

Conflict of Interest: The Authors declare that they have no conflicts of interest.

Ethical approval: All applicable international, national and institutional guidelines for the care and use of animals were followed.

\section{References}

Alberch, P., Gould, S. J., Oster, G. F., \& Wake, D. B. (1979). Size and shape in ontogeny and phylogeny. Paleobiology, 5, 286-317. Retrieved from https://ib.berkeley.edu/labs/wake/1979_Paleobiology_SizShapOnt.pdf

Bass, A. L., Dewar, H., Thys, T., Streelman, J. T., \& Karl, S. a. (2005). Evolutionary divergence among lineages of the ocean sunfish family, Molidae (Tetraodontiformes). Marine Biology, 148, 405-414.

Beddington, J. R., Agnew, D. J., \& Clark, C. W. (2007). Current problems in the management of marine fisheries. Science, 316, $1713-1716$.

Blackwell, B. G., Brown, M. L., \& Willis, D. W. (2000). Relative Weight (Wr) Status and Current Use in Fisheries Assessment and Management. Reviews in Fisheries Science, 8, 1-44. 
Bolger, T., \& Connolly, P. L. (1989). The selection of suitable indices for the measurement and analysis of fish condition. Journal of Fish Biology, 34, 171-182.

Bookstein, F. L. (1996). Biometrics, biomathematics and the morphometric synthesis. Bulletin of Mathematical Biology, 58, 313-365.

Bookstein, F. L. (1997). Landmark methods for forms without landmarks: morphometrics of group differences in outline shape. Medical Image Analysis, 1, 225-243.

Cadrin, S. X., \& Friedland, K. D. (1999). The utility of image processing techniques for morphometric analysis and stock identification. Fisheries Research, 43, 129-139.

Carlson, J. (2017). Observor Progam Mandate \& Authority. NOAA Fisheries National Observer Program. Retrieved from http://www.st.nmfs.noaa.gov/st4/nop/regions/shark_driffnet.html

Carrier, D. R. (2010). Ontogenetic Limits on Locomotor Performance. Physiological Invited Perspectives Zoology in Mammalian Herbivores, $62,1145-1163$.

Cartamil, D. P., \& Lowe, C. G. (2004). Diel movement patterns of ocean sunfish Mola mola off southern California. Marine Ecology Progress Series, 266, 245-253.

Dewar, H., Thys, T., Teo, S. L. H., Farwell, C., O’Sullivan, J., Tobayama, T., ... Karl, S. A. (2010). Satellite tracking the world's largest jelly 
predator, the ocean sunfish, Mola mola, in the Western Pacific. Journal of Experimental Marine Biology and Ecology, 393, 32-42.

Dickie, L. M., Kerr, S. R., \& Boudreau, P. R. (1987). Autotrophic Carbon Sources for Fish of the Central Amazon. Ecological Society of America, 74, 644-652.

Eggold, B. T., \& Motta, P. J. (1992). Ontogenetic dietary shifts and morphological correlates in striped mullet, Mugil cephalus. Environmental Biology of Fishes, 32, 139-158.

Fraser-Brunner, A. (1951). The ocean sunfishes (Family Molidae). Bulletin of the British Museum (Natural History), 1, 87-121. Retrieved from http://archive.org/stream/cbarchive_52333_theoceansunfishfamilymolidae1950/theoceansunfishfamilymolidae1950_djvu.txt

Froese, R. (2006). Cube law, condition factor and weight-length relationships: History, meta-analysis and recommendations. Journal of Applied Ichthyology, 22, 241-253.

Fu, A. L., Hammerschlag, N., Lauder, G. V., Wilga, C. D., Kuo, C. Y., \& Irschick, D. J. (2016). Ontogeny of head and caudal fin shape of an apex marine predator: The tiger shark (Galeocerdo cuvier). Journal of Morphology, 277, 556-564.

Gagnat, M. R., Wold, P.-A., Bardal, T., Øie, G., \& Kjørsvik, E. (2016). Allometric growth and development of organs in ballan wrasse (Labrus bergylta Ascanius, 1767) larvae in relation to different live prey diets and growth rates. Biology Open, 5, 1241-1251.

Giacomini, H. C., Shuter, B. J., \& Baum, J. K. (2016). Size-based approaches to aquatic ecosystems and fisheries science: a symposium in 
honour of Rob Peters. Canadian Journal of Fisheries and Aquatic Sciences, 73, 471-476.

Halsey, L. G., Curran-Everett, D., Vowler, S. L., \& Drummond, G. B. (2015). The fickle P value generates irreproducible results. Nature Methods, 12, 179-185.

Harrod, C., Syväranta, J., Kubicek, L., Cappanera, V., \& Houghton, J. D. R. (2013). Reply to Logan \& Dodge: "Stable isotopes challenge the perception of ocean sunfish Mola mola as obligate jellyfish predators”. Journal of Fish Biology, 82, 10-6.

Hilborn, E., Walters, C. J. (2001). Quantitative fisheries stock assessment: choice, dynamics and uncertainty. New York: Chapman and Hall.

Jarre-Teichmann, A. (1998). The potential role of mass balance models for the management of upwelling ecosystems. Ecology Applications, 8 , 93-103.

Jennings, S., Barnes, C., Sweeting, C. J., \& Polunin, N. V. C. (2008). Application of nitrogen stable isotope analysis in size-based marine food web and macroecological research. Rapid Communications in Mass Spectrometry : RCM, 22, 1673-1680.

Klingenberg, C. . (1996). Multivariate allometry. In D. E. : Marcus, L.F., Corti, M., Loy, A., Naylor, G.J.P., Slice (Ed.), Advances in Morphometrics (pp. 23-50). New York: Plenum Press.

Klingenberg, C. P. (2011). MorphoJ: An integrated software package for geometric morphometrics. Molecular Ecology Resources, 11 , $353-357$. 
Kulbicki, M., Guillemot, N., \& Amanda, M. (2005). A general approach to length-weight relationships for New Caledonian lagoon fishes. Cybium, 29, 235-252.

Kurth, J. a, \& Kier, W. M. (2014). Scaling of the hydrostatic skeleton in the earthworm Lumbricus terrestris. The Journal of Experimental Biology, 217, 1860-7.

Lagler, K. F. (1966). Freshwater fishery biology. Dubuque, Iowa: W.C. Brown Co.

Le Cren, E. D. (1951). The length-weight relationship and seasonal cycle in gonad weight and conditions in the perch (Perca fluviatilis). Freshwater Biological Association, 20, 201-219.

Lee, D. W., \& Brown, C. J. (1998). SEFSC Pelagic Observer Program data summary for 1992-1996. NOAA Technical Memorandum NMFSSEFSC-408

Liebe, R. (2007). Flow Phenomena in Nature: A challenge to engineering design. (R. Liebe, Ed.). Mulheim, Germany: WIT Press.

Loftin, L. K. J. (1985). Quest for Performance: The Evolution of Modern Aircraft. Washington D.C.: U.S. Government Printing Office. Retrieved from https://archive.org/stream/nasa_techdoc_19850023776/19850023776_djvu.txt

Loy, A., Boglione, C., Zanello, L., Ferrucci, L., \& Cataudella, S. (1995). Morphometrics and image analysisas an emerging method to evaluate sea bass larval quality. In J. Lavens, P., Jaspers, E., Roelants (Ed.), Fish and Shellfish Larviculture Symposium (pp. 373-376). 
Mazumder, S. K., Das, S. K., Bakar, Y., \& Ghaffar, M. A. (2016). Effects of temperature and diet on length-weight relationship and condition factor of the juvenile Malabar Blood Snapper. Journal of Zhejiang University-SCIENCE B, 1581, 1-12.

McClain, C. R., Balk, M. A., Benfield, M. C., Branch, T. A., Chen, C., Cosgrove, J., ... Thaler, A. D. (2015a). Data from: Sizing ocean giants: patterns of intraspecific size variation in marine megafauna. Dryad Digital Repository. Retrieved January 1, 2017, from http://dx.doi.org/10.5061/dryad.411mv

McClain, C. R., Balk, M. A., Benfield, M. C., Branch, T. A., Chen, C., Cosgrove, J., ... Thaler, A. D. (2015b). Sizing ocean giants: patterns of intraspecific size variation in marine megafauna. PeerJ, 3, e715.

Murphy, B. R., Willis, D. W., \& Springer, T. A. (1991). The Relative Weight Index in Fisheries Management: Status and Needs. Fisheries, 16, 30-38. Retrieved from http://www.tandfonline.com/doi/pdf/10.1577/1548-

8446\%25281991\%2529016\%253C0030\%253ATRWIIF\%253E2.0.CO\%253B2?needAccess=true

Nakamura, I., Goto, Y., \& Sato, K. (2015). Ocean sunfish rewarm at the surface after deep excursions to forage for siphonophores. Journal of Animal Ecology, 84, 590-603.

Nakamura, I., \& Sato, K. (2014). Ontogenetic shift in foraging habit of ocean sunfish Mola mola from dietary and behavioral studies. Marine Biology, 161, 1263-1273. 
Nyegaard, M., Sawai, E., Gemmell, N., Gillum, J., Loneragan, N. R., Yamanoue, Y., \& Stewart, A. L. (2017). Hiding in broad daylight: molecular and morphological data reveal a new ocean sunfish species (Tetraodontiformes: Molidae) that has eluded recognition. Zoological Journal of the Linnean Society, 1-28.

Ogle, D. (2013). fishR Vignette: Length-Weight Relationships. Retrieved January 1, 2017, from http://derekogle.com/fishR/examples/oldFishRVignettes/LengthWeight.pdf

Ogle, D. H. (2017). FSA: Fisheries Stock Analysis.

Petersen, S., \& McDonell, Z. (2007). A bycatch assessment of the Cape horse mackerel Trachurus trachurus capensis mid- water trawl fishery off South Africa. Birdlife/WWF Responsible Fisheries Programme Report 2002-2005.

Phillips, N. D., Reid, N., Thys, T., Harrod, C., Payne, N., Morgan, C., ... Houghton, J. D. R. (2017). Applying species distribution modelling to a data poor, pelagic fish complex: the ocean sunfishes. Journal of Biogeography, 12pp.

Polly, D. (2013). Geometric morphometrics. Retrieved from http://www.indiana.edu/ g404/Labs/Lab 10 Geometric morphometrics.pdf

Pope, E. C., Hays, G. C., Thys, T. M., Doyle, T. K., Sims, D. W., Queiroz, N., ... Houghton, J. D. R. (2009). The biology and ecology of the ocean sunfish Mola mola: A review of current knowledge and future research perspectives. Reviews in Fish Biology and Fisheries, 20, 471487. 
Quillin, K. (1998). Ontogenetic scaling of hydrostatic skeletons: geometric, static stress and dynamic stress scaling of the earthworm lumbricus terrestris. The Journal of Experimental Biology, 201, 1871-83. Retrieved from http://www.ncbi.nlm.nih.gov/pubmed/9600869

R Development Core Team. (2008). R Development Core Team. ISBN 3-900051-07-0. Retrieved from http://www.r-project.org

Rosli, N. A. M., \& Isa, M. M. (2012). Length-weight and length-length relationship of longsnouted catfish, Plicofollis argyropleuron (Valenciennes, 1840) in the northern part of Peninsular Malaysia. Tropical Life Sciences Research, 23, 59-65.

Sawai, E., Yamanoue, Y., Jawad, L., Al-Mamry, J., \& Sakai, Y. (2017). Molecular and Morphological Identification of Mola Sunfish Specimens (Actinopterygii: Tetraodontiformes: Molidae) from the Indian Ocean. Species Diversity, 22, 7-27.

Sawai, E., Yamanoue, Y., Nyegaard, M., \& Sakai, Y. (2017). Redescription of the bump-head sunfish Mola alexandrini (Ranzani 1839), senior synonym of Mola ramsayi (Giglioli 1883), with designation of a neotype for Mola mola (Linnaeus 1758) (Tetraodontiformes: Molidae). Ichthyological Research.

Schneider, C. A., Rasband, W. S., \& Eliceiri, K. W. (2012). NIH Image to ImageJ: 25 years of image analysis. Nature Methods, 9, 671-675.

Silvani, L., Gazo, M., \& Aguilar, a. (1999). Spanish driftnet fishing and incidental catches in the western Mediterranean. Biological Conservation, 90, 79-85.

Sims, D. W., Queiroz, N., Doyle, T. K., Houghton, J. D. R., \& Hays, G. C. (2009). Satellite tracking of the World's largest bony fish, the ocean 
sunfish (Mola mola L.) in the North East Atlantic. Journal of Experimental Marine Biology and Ecology, 370, $127-133$.

Sousa, L. L., Queiroz, N., Mucientes, G., Humphries, N. E., \& Sims, D. W. (2016). Environmental influence on the seasonal movements of satellite-tracked ocean sunfish Mola mola in the north-east Atlantic. Animal Biotelemetry, 4, 7.

Sousa, L. L., Xavier, R., Costa, V., Humphries, N. E., Trueman, C., Rosa, R., ... Queiroz, N. (2016). DNA barcoding identifies a cosmopolitan diet in the ocean sunfish. Scientific Reports, 6, 28762.

Spence, A. J. (2009). Scaling in Biology. Current Biology, 19, 57-61.

Syväranta, J., Harrod, C., Kubicek, L., Cappanera, V., \& Houghton, J. D. R. (2012). Stable isotopes challenge the perception of ocean sunfish Mola mola as obligate jellyfish predators. Journal of Fish Biology, 80, 225-31.

Thompson, D. W. (1917). On growth and form. Cambridge: Cambridge University Press.

Thys, T. M., Hearn, A., Weng, K. C., Ryan, J., \& Penaherrera-, C. R. (2017). Satellite Tracking and Site Fidelity of Short Ocean Sunfish, Mola ramsayi, in the Galapagos Islands. Journal of Marine Biology.

Thys, T. M., Ryan, J. P., Dewar, H., Perle, C. R., Lyons, K., O’Sullivan, J., ... Bograd, S. J. (2015). Ecology of the Ocean Sunfish, Mola mola, in the southern California Current System. Journal of Experimental Marine Biology and Ecology, 471, 64-76. 
Vasconcellos, M., Mackinson, S., Sloman, K., \& Pauly, D. (1997). The stability of trophic mass-balanced models of marine ecosystems: a comparative analysis. Ecological Modelling, 100, 125-134.

Vogel, S. (1994). Life in moving fluids: The physical biology of flow (2nd ed.). Princeton University Press.

Watanabe, Y., \& Sato, K. (2008). Functional dorsoventral symmetry in relation to lift-based swimming in the ocean sunfish Mola mola. PLoS ONE, 3, e3446.

Werner, E. E., \& Gillian, J. F. (1984). The ontogenetic niche and species interactions in size-structured populations. Annual Reveiw of Ecology, Evolution and Systematics, 15, 393-425.

Weston, E. (2003). Evolution of ontogeny in the hippopotamus skull: using allometry to dissect developmental change. Biological Journal of the Linnean Society, 80, 625-638. Retrieved from https://academic.oup.com/biolinnean/article-lookup/doi/10.1111/j.1095-8312.2003.00263.x

Witt, M. J., Bonguno, E. A., Broderick, A. C., Coyne, M. S., Formia, A., Gibudi, A., ... Godley, B. J. (2014). Tracking leatherback turtles from the world $\hat{a} €^{\mathrm{TM}} \mathrm{s}$ largest rookery : Assessing threats across the South Atlantic Tracking leatherback turtles from the world â $€^{\mathrm{TM}} \mathrm{s}$ largest rookery : assessing threats across the South Atlantic Subject collections. Proceedings of the Royal Society B: Biological Sciences, 278, 2338-47.

Wootton, R. J. (1990). Ecology of Teleost Fishes. Upper Saddle River, New Jersey, USA: Chapman and Hall. 
Yoshita, Y., Yamanoue, Æ. Y., Sagara, Æ. K., Nishibori, M., Kuniyoshi, Æ. H., \& Umino, Æ. T. (2009). Phylogenetic relationship of two Mola sunfishes ( Tetraodontiformes : Molidae ) occurring around the coast of Japan, with notes on their geographical distribution and morphological characteristics. Ichthyological Research, 56, 232-244.

Zelditch, M. L., Swiderski, D. L., Sheets, D. H., \& Fink, W. L. (2004). Geometric Morphometrics for Biologists: A Primer. Geometric Morphometrics for Biologists-A Primer. New York, USA: Elsevier. 


\section{Tables and Figures}

Table 1. Results of linear models from all $\log _{e}$-scaled Mola traits plotted against total length, including model fit $R^{2}$ value, slope estimate (b) with confidence intervals $(\mathrm{Cl})$, growth classification: $(\mathrm{A})$ allometric, or $(\mathrm{I})$ isometric and degrees of freedom (DF)

\begin{tabular}{|c|c|c|c|c|c|c|c|}
\hline Metric & Units & Equation of the Linear Model & $\begin{array}{c}\mathrm{R}^{2} \\
\text { Value }\end{array}$ & $\begin{array}{c}\mathrm{b} \\
\text { estimate }\end{array}$ & $\begin{array}{l}\mathrm{Cl} \\
+/-\end{array}$ & Growth & DF \\
\hline Body Mass & g & $\log _{e}($ Mass $)=-3.25+3.09 * \log _{e}(T L)$ & 0.98 & 3.09 & 0.08 & Likely I & 439 \\
\hline Body Width & $\mathrm{cm}$ & $\log _{e}($ Body Width $)=-0.24+0.96{ }^{*} \log _{e}(T L)$ & 0.93 & 0.96 & 0.1 & A & 123 \\
\hline Width Fin Tips & $\mathrm{cm}$ & $\log _{e}($ Fin Tips $)=0.90+0.86 * \log _{e}(T L)$ & 0.97 & 0.86 & 0.03 & A & 365 \\
\hline Dorsal Fin Length & $\mathrm{cm}$ & $\log _{e}($ Dorsal Fin Length $)=-0.91+0.99 * \log _{e}(T L)$ & 0.90 & 0.99 & 0.13 & A & 93 \\
\hline Dorsal Fin Width & $\mathrm{cm}$ & $\log _{e}($ Dorsal Fin Width $)=-2.35+1.35 * \log _{e}(T L)$ & 0.91 & 1.35 & 0.16 & A & 110 \\
\hline Anal Fin Length & $\mathrm{cm}$ & $\log _{e}($ Anal Fin Length $)=-0.55+0.91 * \log _{e}(T L)$ & 0.93 & 0.91 & 0.1 & A & 94 \\
\hline Anal Fin Width & $\mathrm{cm}$ & $\log _{e}($ Anal Fin Width $)=-1.71+1.01 * \log _{e}(T L)$ & 0.94 & 1.01 & 0.09 & A & 110 \\
\hline Clavus & $\mathrm{cm}$ & $\log _{e}($ Clavus $)=-1.43+0.92 * I \log _{e}(T L)$ & 0.85 & 0.92 & 0.75 & A & 110 \\
\hline Eye Diameter & $\mathrm{cm}$ & $\log _{e}($ Eye Diameter $)=-1.64+0.71 * \log _{e}(T L)$ & 0.75 & 0.71 & 0.17 & $A$ & 92 \\
\hline Mouth Size & $\mathrm{cm}$ & $\log _{e}($ Mouth Size $)=-2.31+0.84{ }^{*} \log _{e}(T L)$ & 0.68 & 0.84 & 0.28 & A & 66 \\
\hline Pectoral Fin Length & $\mathrm{cm}$ & $\log _{e}(\operatorname{Pec}$ Fin Length $)=-1.69+0.94 * \log _{e}(T L)$ & 0.90 & 0.94 & 0.78 & A & 106 \\
\hline Pectoral Fin Width & $\mathrm{cm}$ & $\log _{e}(P e c$ Fin Width $)=-2.07+0.99 * \log _{e}(T L)$ & 0.91 & 0.99 & 0.12 & $A$ & 107 \\
\hline Dorsal Fin Area & $\mathrm{cm}^{2}$ & $\log _{e}($ Dorsal Fin Area $)=-8.23+2.16 * \log _{e}(T L)$ & 0.93 & 2.16 & 0.27 & A & 68 \\
\hline Anal Fin Area & $\mathrm{cm}^{2}$ & $\log _{e}($ Anal Fin Area $)=-7.66+2.02 * \log _{e}(T L)$ & 0.93 & 2.02 & 0.28 & $A$ & 63 \\
\hline Body Area & $\mathrm{cm}^{2}$ & $\log _{e}($ Body Area $)=-4.59+1.85 * \log _{e}(T L)$ & 0.96 & 1.85 & 0.15 & $A$ & 92 \\
\hline Total Area & $\mathrm{cm}^{2}$ & $\log _{e}($ Total Area $)=-4.61+1.90 * \log _{e}(T L)$ & 0.98 & 1.90 & 0.16 & A & 47 \\
\hline
\end{tabular}


Table 2. Results of the principal component analysis (PCA) run on Mola landmarks

\begin{tabular}{clcc}
\hline PC & Eigenvalues & \% Variance & Cumulative $\%$ \\
\hline 1 & 0.00415753 & 25.291 & 25.291 \\
2 & 0.00344979 & 20.986 & 46.277 \\
3 & 0.00231237 & 14.067 & 60.344 \\
4 & 0.00187197 & 11.388 & 71.732 \\
5 & 0.00152488 & 9.276 & 81.008 \\
6 & 0.0007784 & 4.735 & 85.743 \\
7 & 0.0006944 & 4.224 & 89.968 \\
8 & 0.00053078 & 3.229 & 93.196 \\
9 & 0.00034187 & 2.08 & 95.276 \\
10 & 0.00022319 & 1.358 & 96.634 \\
11 & 0.00017813 & 1.084 & 97.717 \\
12 & 0.00010912 & 0.664 & 98.381 \\
13 & 0.00009598 & 0.584 & 98.965 \\
14 & 0.00008164 & 0.497 & 99.462 \\
15 & 0.00004976 & 0.303 & 99.764 \\
16 & 0.00003872 & 0.236 & 100.000 \\
\hline
\end{tabular}




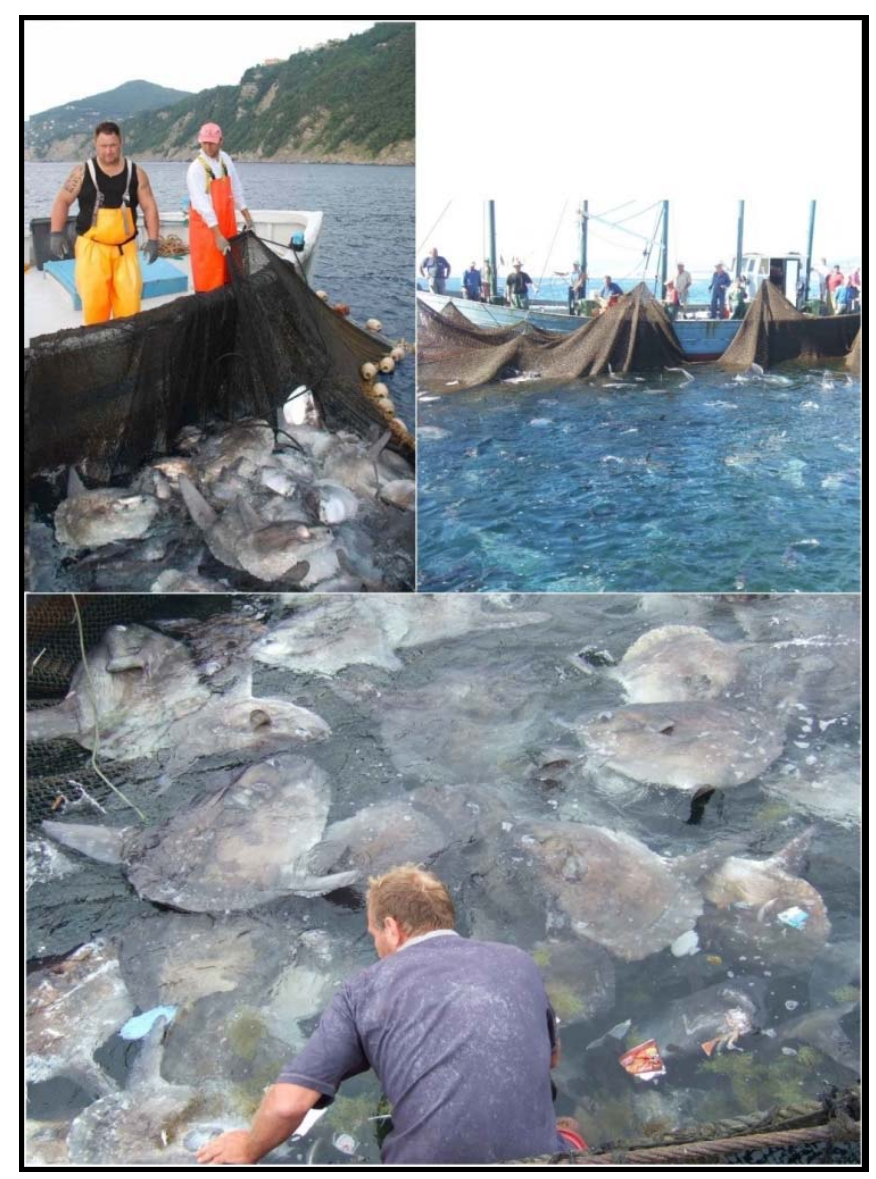

Figure 1. Mass bycatch of Mola from the Mediterranean Sea (photo sources, top left; Valentina Cappanera, top right \& lower; Lukas Kubicek). 


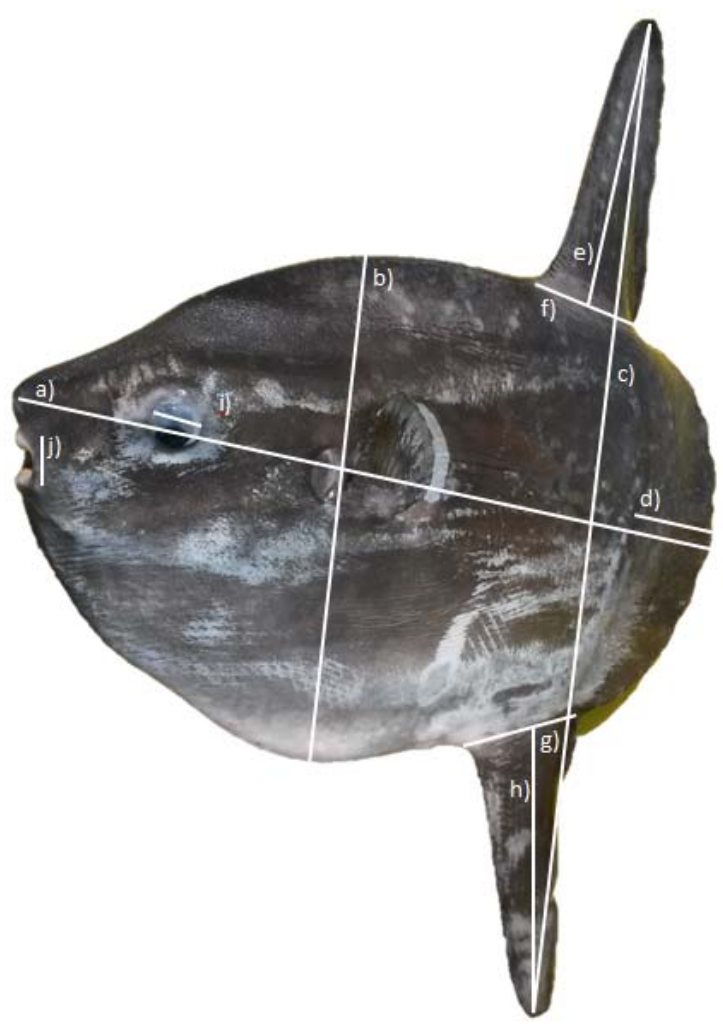

Figure 2. Length measurements collected from Mola; a) total length, tip of snout to end of clavus; b) body width, cross section from dorsal surface to deepest part of ventral keel; c) width of fintips; d) width of clavus; e) dorsal fin length; f) dorsal fin width; g) anal fin width; h) anal fin length; i) eye diameter; j) mouth width. 

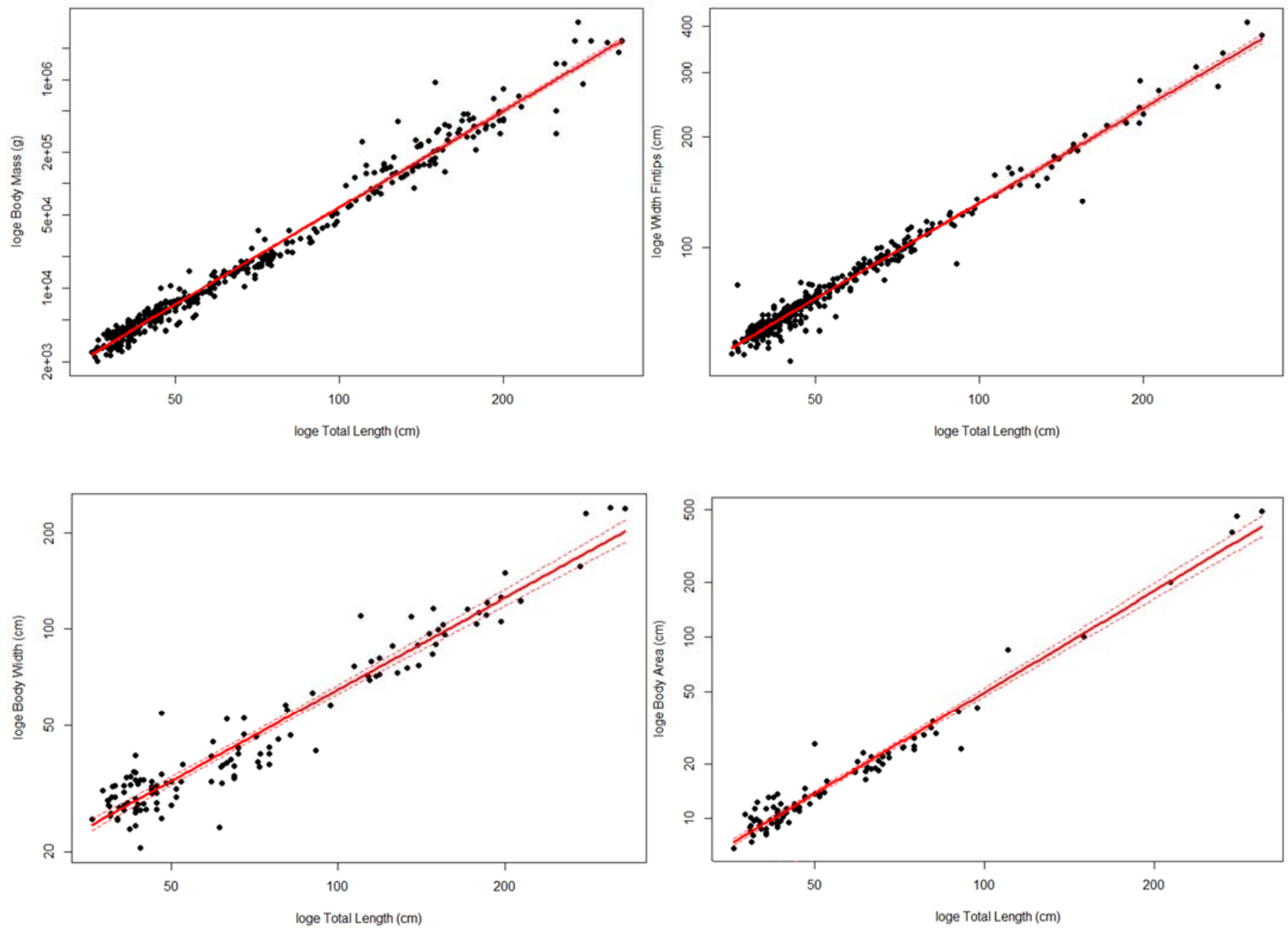

Figure 3. Linear models with 95\% confidence intervals applied to all Mola traits plotted on $\log _{\mathrm{e}}$ scale against total length to illustrate the relationship between variables. Full model plots for all data from Table 1 in Supplementary Materials. 


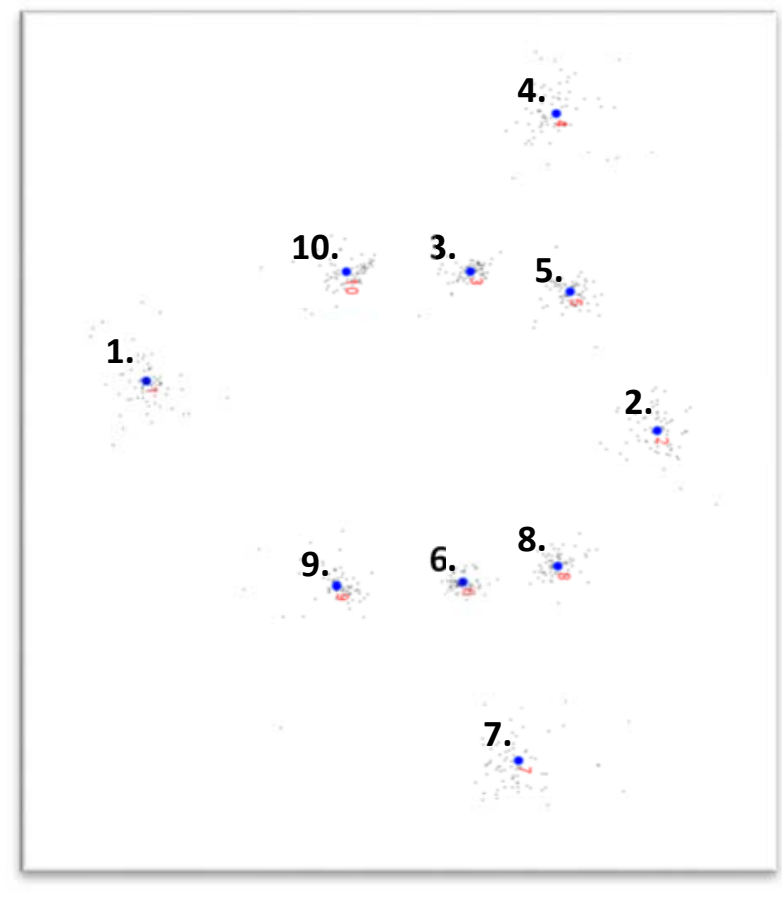

Figure 4. Landmark positioning on Mola for geometric morphometric analyses $(n=71)$. The scattering of points at each landmark suggests considerable variation in sunfish shape even when controlling for size. (1. Tip of snout, 2. Tip of clavus, 3. Leading edge of dorsal fin, 4. Tip of dorsal fin, 5. Trailing edge of dorsal fin, 6. Leading edge of anal fin, 7. Tip of dorsal fin, 8. Trailing edge of dorsal fin, 9. Deepest point of ventral keel, 10. Deepest point of dorsal keel. 


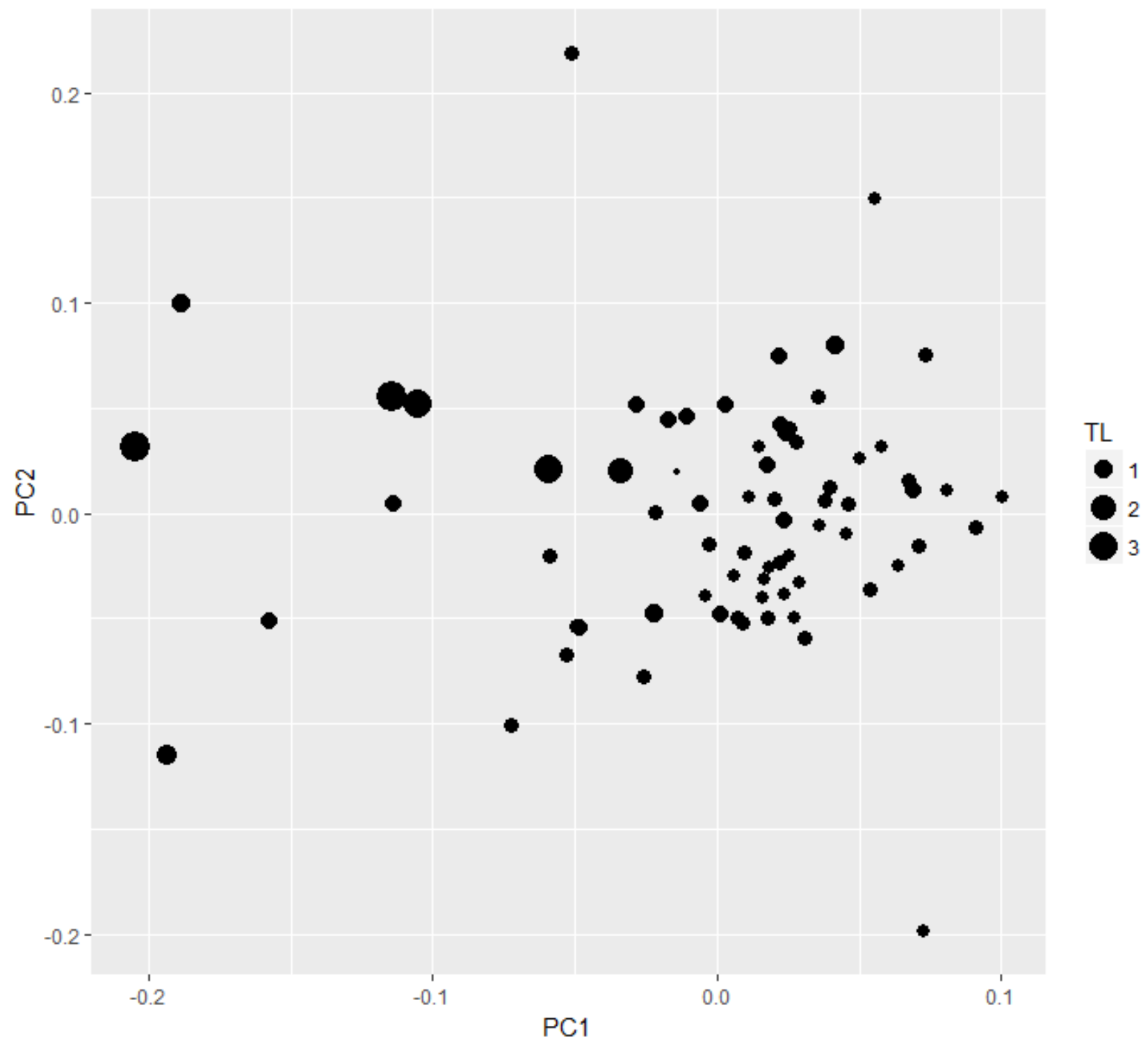

Figure 5. Morphospace plot showing principal component analysis of Mola shape. This illustrates the first and second principle components with size of marker indicating total length of fish (with marker size shown for fish of 1, 2 and 3 meters TL). This plot suggests there may be significant variation in body shape ontogenetically with small sizes clustering positively in PC1, becoming more negative as length increases. 


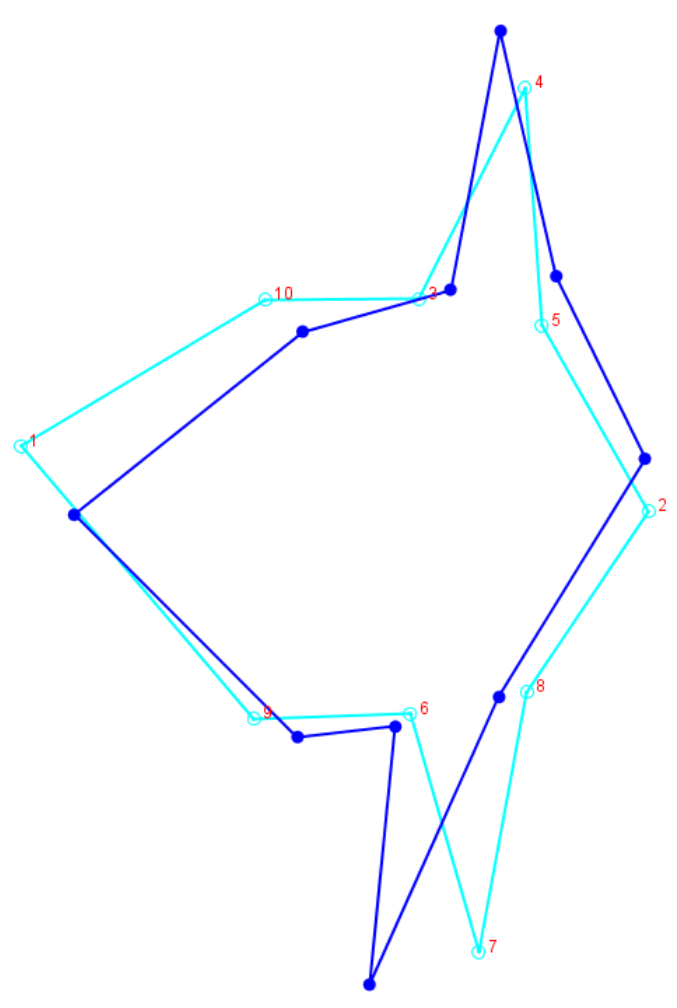

1

2 Figure 6. Deformation wireframe models to illustrate shape changes of Mola along principle 3 component (PC1) axis (scale 0.2). From these plots it appears that smaller fish (dashed, 4 dark blue outline, 'small' size class) have shorter distances between landmarks with fin tips 5 slightly more elongated and angled towards the snout. The snout tip is closer to the body 6 with a deep ventral keel. Fish in the larger size classes (continuous, light blue outline, 'large' 7 size class) have landmarks more widely spaced, with the snout tip protruding further from 8 the body and fin tips appearing slightly shorter and positioned further back. 